\title{
Khotbah Ekspositori yang Alkitabiah Menurut Nehemia 8:1-9
}

\author{
Sigit Ani Saputro \\ Sekolah Tinggi Teologi Torsina Surakarta \\ sigitanisaputro@gmail.com
}

\section{Article History \\ Received: \\ Mei 2017 (printed) \\ Published: \\ Mei 2017 (printed)}

Keywords:

Bible; expository;

Nehemiah;

preacher; sermon;

\begin{abstract}
Sermon is a part of a ministry in the church service. It oftenly considered as a way to convey the true God's Word. However, not every sermon is biblical. This article aimed to give a description of a biblical expository sermon. This is a biblical research with exposition approach on Nehemiah 8:1-9. And the conclusion of the research gave four criterions of biblical expository sermon, those are: Preacher must have a wide knowledge, sermon must be text oriented, as an embodiment of a ministry and compliment to God, have a specific ability to communicate the Bible's contents.
\end{abstract}

\begin{abstract}
Abstrak
Khotbah merupakan salah bentuk pelayanan yang dilakukan dalam ibadah. Khotbah sering diartikan sebagai sarana menyampaiakan kebenaran firman Tuhan. Namun tidak semua khotbah bersifat alkitabiah. Artikel ini bertujuan untuk memberikan deksripsi tentang khotbah yang alkitabiah. Artikel ini merupakan penelitian teks Alkitab dengan pendekatan eksposisi pada Nehemia 8:1-9. Kesimpulan memberikan empat kriteria sebagai khotbah ekspositori yang alkitabiah, yaitu: Pengkhotbah harus memiliki pengetahuan yang luas, khotbah harus tetap berdasarkan kepada teks, sebagai suatu wujud pelayanan dan pujian kepada Allah, memiliki ketrampilan khusus dalam mengkomunikasikan isi kitab.$$
\text { memiliki ketrampilan khusus dalam mengkomunikasikan isi kitab. }
$$

Kata kunci:

Alkitab; ekspositori; khotbah; Nehemia; pengkhotbah

\section{Pendahuluan}

Khotbah merupakan hal penting dalam sebuah ibadah. Pelayanan mimbar ini diasosiasikan dengan pelayanan untuk menyampaikan pesan Tuhan atau firman Tuhan. Namun tidak semua khotbah yang disampaikan melalui mimbar ibadah Minggu atau ibadah lainnya dapat diterima sebagai sesuatu yang alkitabiah; karena ada semacam tendensi untuk menggunakan khotbah sebagai media menghibur jemaat, sehingga tidak sedikit konten khotbah lebih banyak mengumbar hal jenaka dibandingkan pengajaran 
Alkitab. ${ }^{1}$ Itu sebabnya diperlukan lebih banyak lagi model khotbah yang dapat menyampaikan pengajaran sehat demi membangun dasar gereja yang kuat.

Nehemia 8:1-9 merupakan salah satu bentuk ideal dari khotbah-khotbah yang dilakukan para nabi atau hamba Tuhan pada zaman Alkitab. Khotbah-khotbah dengan orientasi pengajaran memang sangat dibutuhkan, terelebih pengajaran itu bukanlah asal saja, melainkan melewati kajian dan proses yang benar. Salah satu bentuk khotbah yang ditunjukkan dari nas di atas adalah khotbah ekspositori, di mana proses eksposisi menjadi metodenya. Nas Nehemia 8:1-9 memberikan gambaran tentang tahapan atau proses khotbah ekspositori yang baik dan benar.

Nehemia 8 dimulai dengan penjelasan tentang inisiatif orang Israel yang telah kembali dari pembuangan, “...ketika tiba bulan ketujuh, sedang orang Israel telah menetap di kota-kotanya, maka serentak berkumpullah rakyat di halaman di depan pintu gerbang Air, mereka meminta kepada Ezra, Ahli kitab itu, supaya ia membawa kitab Taurat Musa, yakni kitab hukum yang diberikan Tuhan kepada Israel..." (Neh. 8:1).

Ayat ini disambung dengan cerita istimewa (pasal. 8, 9, dan 10), di mana orang mengadakan pertemuan agama istimewa. Mereka sendirilah yang meminta supaya diberi penjelasan lagi mengenai Taurat. Mereka mengadakan suatu hari di mana mereka mengakui kegagalan mereka, dan mengakui pula kemurahan dan kesabaran Tuhan (ps. 9). ${ }^{2}$ Dalam hal ini Ezra ditunjuk supaya membacakan Taurat bagi mereka. Ezra sebagai ahli kitab ternyata tidak hanya membacakan hukum Taurat itu tetapi juga memberikan keterangan- keterangan sehingga pembacaan kitab tersebut dimengerti.

Jika dilihat secara sepintas, sepertinya nats ini tidak membicarakan tentang adanya suatu khotbah. Kata khotbah dalam nats tersebut tidak tersurat secara langsung, karena dalam Alkitab bahasa Indonesia hanya menggunakan kata "membacakan." Tetapi dalam nats tersebut didapati ayat yang berkata: “...bagian-bagian dari pada kitab itu, yakni Taurat Allah, dibacakan dengan jelas, dengan diberi keterangan-keterangan,

\footnotetext{
${ }^{1}$ Kevin Tonny Rey, "KHOTBAH PENGAJARAN VERSUS KOTBAH KONTEMPORER," DUNAMIS ( Jurnal Teologi dan Pendidikan Kristiani ) Vol.1, no. 1 (2016): 31-51, www.sttintheos.ac.id/ejournal/index.php/dunamis.

${ }^{2}$ J. Sidlow Baxter, Menggali Isi Alkitab, peny., G. M. A Nainggolan dan H. A. Oppusunggu (Jakarta: Yayasan Komunikasi Bina Kasih, 1997), Jil. 1, bag. Kejadian sampai Ester, pen., Sastro Soedirdjo, 472.
} 
sehingga pembacaan dimengerti." 3 Kata "membaca" dan kata "diberi keteranganketerangan" merupakan kata yang patut dicermati. Kata-kata ini memberikan suatu keterangan bahwa ada salah satu unsur khotbah yang ada di nats itu yaitu dengan memberikan keterangan pada pembacaan kitab itu. Dari nats ini sekilas dapat diindikasikan bahwa Nats itu berisi suatu pola khotbah yang Alkitabiah.

Selain dari nats di atas didapati pemakaian kata קרא (qara) yang diterjemahkan “membacakan.” Selain dipakai untuk menjelaskan kata "membacakan” kata קרץ juga dapat memiliki banyak arti. Pemakaian pertama kali digunakan Allah dalam masa penciptaan, yang terlihat dari yang berkata “... dan Allah menamai terang itu siang, dan gelap itu malam. Jadilah petang dan jadilah pagi, itulah hari pertama."4 Kata yang dipakai dalam ayat ini adalah kata קרא. Kata itu dapat diterjemahkan "menamakan.", Arti yang sama dipakai dalam kitab Mazmur 147:4 yaitu diterjemahkan "memberi nama." Jadi kata קרא dapat diterjemahkan memberi nama. Allah mengijinkan manusia untuk memberi nama binatang sebagai pernyataan yang kongret atas kedaulatan yang telah dimiliki manusia. ${ }^{6}$ Konsep memberi nama dalam masa penciptaan berhubungan erat dengan cara proses penciptaan itu sendiri. Dalam hal ini perlu diingat kembali bahwa Allah menciptakan melalui firman (Kej. 1:3). Jadi kata ini berhubungan erat dengan penyampaian firman yaitu kata-kata yang keluar dari Allah sendiri.

Kedua, קר digunakan untuk mengindikasikan suatu panggilan seseorang untuk tugas khusus. ${ }^{7}$ Sebagai contoh dalam Keluaran 2:7, saudara Musa bertanya kepada putri Firaun apakah ia perlu memanggil seseorang untuk menyusui bayi itu. Contoh lain adalah ketika Israel dipanggil Allah untuk menjadi umatnya (Yes. 65:12), demikian halnya dengan panggilan orang non Yahudi dalam pengharapan Mesianik (Yes. 55:5).

Ketiga, קרא perarti memanggil dengan suara nyaring atau keras dengan maksud untuk memperoleh perhatian dari seseorang sehingga terjadi hubungan timbal balik. $^{8}$ Sering kali kata kerja digunakan untuk menjelaskan suatu komunikasi, sejajar

\footnotetext{
${ }^{3}$ Nehemia 8:9.

${ }^{4}$ Kejadian 1:5.

${ }^{5}$ Vine's, Bible Explorer, Copyright 1995, Epiphhany Software. All rights reserved. [CD-ROM]. ${ }^{6}$ Ibid.

${ }^{7}$ Theological Wordbook of the Old Testatement, Bible Explorer, Copyright 1995, Epiphhany Software. All rights reserved. [CD-ROM].

${ }^{8}$ Vine's: Bible Explorer, Copyright 1995, Epiphhany Software. All rights reserved. [CD-ROM].
} 
dengan kata אַָָָָר (amar) artinya berkata. ${ }^{9}$ Kejadian 3:9 memberikan contoh adanya pemakaian kedua kata tersebut. Kempat, kata קרא berarti memproklamirkan atau mengumumkan. ${ }^{10}$ Dalam Nehemia, kata yang dipakai untuk menjelaskan kata "membacakan" dapat diindikasikan sebagai suatu bentuk proklamasi atau juga penegasan terhadap panggilan khusus. Oleh karena itu jelas bahwa dalam Nehemia 8:19 tersirat suatu tindakan berkhotbah.

Willem A. van Gemeren menjelaskan tujuan dasar penggunaan kata קרא adalah untuk menarik perhatian dari pendengar terhadap dirinya sendiri dengan menggunakan suara seseorang dengan tujuan untuk menimbulkan adanya hubungan dengan orang lain. ${ }^{11}$ Ia juga sependapat bahwa kata קרא dapat diterjemahkan untuk pengertian "pengumuman atau penegasan."12 Dalam Nehemia 8:3 kata קרא berbentuk qal imperfek. ${ }^{13}$ Dalam bentuk qal, kata ini dapat berarti khotbah. ${ }^{14}$ Konteks dekat dari ayat sebelum dan sesudah nats tersebut memberikan gambaran bahwa Ezra adalah seorang ahli kitab. Selain itu dalam ayat tiga diberikan keterangan tentang keadaan pendengar saat itu yaitu mereka yang dapat mendengar dan mengerti (Neh. 8:3). Selanjutnya diulangi lagi dalam ayat keempat dengan kata “. . . dihadapan laki-laki dan perempuan dan semua yang dapat mengerti." Ini memberikan suatu keterangan bahwa pembacaan kitab dalam nats tersebut merupakan suatu bentuk khotbah yang disampaikan oleh Ezra.

\section{Metodologi}

Metode yang digunakan dalam penelitian literatur dengan pendekatan eksposisi kitab Nehemia 8:1-9 untuk mendeskripsikan khotbah ekspositori yang alkitabiah sesuai dengan refleksi nas tersebut. Penulis meneliti nas yang berkaitan dengan Nehemia 8:1-9 sebagai referensi paralel yang dibutuhkan untuk memperjelas maksud dari nas yang dibahas.

\section{Analisis dan Hasil Pembahasan}

${ }^{9}$ Ibid.

${ }^{10}$ Ibid.

${ }^{11}$ Willem A. Van Gemeren, "qara," dalam The New International Dictionary of Old Testament Theology and Exegesis, peny., Michael L. Brown (Cumbria: Paternoster Press, 1996), 3: 971.

${ }^{12}$ Ibid.

${ }^{13}$ Michael S. Bushell: BibleWorks Hermenutika, Computer Bible Research Software, [CD ROM]

${ }^{14}$ William Wilson, Old Testament Word Studies (McLean: Mac Donald Publlishing Co., tt), 323 
Dengan memperhatikan peristiwa yang disajikan dalam kitab Nehemia pasal 8, maka jelas bahwa khotbah Ezra dapat dijadikan sebagai sebuah contoh khotbah yang Alkitabiah. Hal ini disebabkan karena khotbah Ezra tersebut memiliki karakteristik yang sesuai dengan pemahaman khotbah yang Alkitabiah. Karakterisik khotbah yang terdapat dalam Nehemia 8:1-9 adalah sebagai berikut:

\section{Disampaikan oleh Orang yang Berkompeten (ayat 2, 5)}

Prinsip pertama sebuah khotbah yang Alkitabiah terlihat dari ayat yang kedua yang berbunyi “. . . mereka meminta kepada Ezra, ahli kitab itu, supaya ia membawa kitab Taurat Musa, yakni kitab hukum yang diberikan TUHAN kepada Israel."15 Dalam ayat tersebut terdapat keterangan mengenai pribadi pengkhotbah. Dapat diindikasikan bahwa pribadi pengkhotbah merupakan seorang yang memiliki kompetensi dalam bidangnya. Hal ini terlihat dari kata "ahli kitab" dalam ayat itu. Pembahasan berikut akan menjelaskan pribadi pengkhotbah dan juga identitas pengkhotbah itu sebagai seorang yang berkompeten dalam bidangnya.

Khotbah yang tersirat dalam Nehemia 8:1-9 bukan saja disampaikan oleh orang awam atau jemaat biasa, melainkan oleh Ezra. Ezra adalah seorang imam di antara orang-orang Israel yang kembali ke Yerusaem di bawah pemerintahan Zerubababel (Neh. 12:1). Ia adalah imam, yaitu orang kedua yang memimpin kembalinya orang Israel dari pembuangan Babel pada tahun 459 SM. Gelar Ezra sebagai ahli kitab bukan saja pemberian dari seseorang, akan tetapi karena bukti-bukti yang menunjukkan bahwa ia adalah seseorang yang telah mempelajari kitab sebelumnya. Dalam Ezra 7:10 disebutkan bahwa ia seorang yang telah bertekad untuk meneliti hukum Taurat Tuhan dan melakukannya serta mengajar ketetapan dan peraturan di antara Israel. Seorang penulis berpendapat bahwa ia bukan saja seorang imam, tetapi juga menjadi seorang guru. ${ }^{16}$ Hal ini nampak dalam pelayanannya ketika memberikan suatu pengajaran dalam kitab Nehemia 8:1-9 yang menimbulkan reaksi berupa kebangunan Rohani. Dari gelargelar yang dikenakan kepadanya dalam pendahuluan catatan pribadinya, yang terpenting adalah "ahli Taurat."

Sosok Ezra sebagai seorang yang berkompeten secara biblikal tampak jelas dalam kitab Ezra 7: 6-10. Itu terlihat jelas dari ayat yang berbunyi, ”...Sebab Ezra telah bertekad untuk meneliti Taurat Tuhan dan melakukannya serta mengajar ketetapan dan

\footnotetext{
${ }^{15}$ Nehemia 8:2.

${ }^{16}$ Michael S. Bushell: BibleWorks Hermeneutika, Computer Bible Research Software, [CD ROM]
} 
peraturan di antara orang Israel. ${ }^{17}$ Kata kerja dalam Ezra 7:10 yang dinyatakan dengan

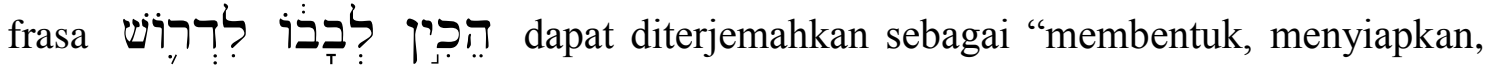
menetapkan hatinya untuk tujuan tertentu."18 Dalam nats tersebut dapat diambil keterangan mengenai pribadi Ezra yaitu bahwa ia adalah seorang yang bertekad mempelajari Taurat, melakukannya serta mengajarkan Taurat itu kepada orang Israel. Seperti yang dikatakan oleh Steven J. Lawson bahwa sebelum ia membuka mulutnya untuk mengajar orang lain, Ezra hidup dalam ketaatan dan melakukan apa yang ia ajarkan dan khotbahkan. Tapi sebelum dia melakukan dan mengajarkan firman, terlebih dahulu ia menyerahkan hatinya untuk mempelajari hukum Taurat itu. ${ }^{19}$ Lebih lanjut Lawson menjelaskan beberapa hal praktis yang dilakukan Ezra dalam mempelajari Taurat Tuhan sehingga ia berhasil menjadi seorang ahli. Pertama; Ezra menghabiskan waktu untuk belajar. Kata "bertekad" dalam Ezra 7:10 memberikan pengertian bahwa ia menyiapkan hatinya dan menghabiskan waktunya untuk mempelajari Taurat Tuhan. $^{20}$

Kedua, Ezra mempelajari Taurat itu dengan tekun. Ezra telah berkomitmen dengan tekun dan kompeten untuk meneliti firman Allah. Kata "meneliti" dalam bahasa Ibrani adalah דרש (darash). Selain berarti "meneliti," kata itu memiliki arti "melihat dengan sungguh-sungguh," dan juga dapat berarti "mengadakan penyelidikan.,"21 Dengan kata lain Ezra adalah seorang yang telah mempelajari Taurat dengan mengadakan penyelidikan dan penelitian yang dilakukan dengan tekun dan sungguhsungguh. $^{22}$

Ketiga, Ezra mempelajari Taurat Musa secara komprehensif. Ini terlihat dari cara ia belajar "Taurat Tuhan" melakukan dan mengajar "ketetapan dan peraturan." Penyelidikan menyeluruh dalam mempelajari Taurat Tuhan, ketetapan, dan peraturan mengindikasikan bahwa ia belajar tentang semua segi firman Tuhan. ${ }^{23}$ Dengan penyelidikan yang dilakukan secara menyeluruh dan lengkap ini, maka sudah dapat

\footnotetext{
${ }^{17}$ Ezra 7:10.

${ }^{18}$ Laird Harris, Theological Wordbook of the Old Testament (Chichago: Mody Press, 1981), I: 700-702.

${ }^{19}$ Steven J. Lawson, “The Pattern of Biblical Preaching an Expository Study of Ezra 7:10 dan Nehemia 8:18," dalam Bibliotecha Sacra, October-Desember 2001, 458.

${ }^{20}$ Ibid., 454.

${ }^{21}$ Michael S. Bushell: BibleWorks Hermeneutika, Computer Bible Research Software, [CD ROM]

${ }^{22}$ Steven J. Lawson, "The Pattern of Biblical Preaching an Expository Study of Ezra 7:10 dan Nehemia 8:18," dalam Bibliotecha Sacra October-Desember 2001.

${ }^{23}$ Ibid., 457
} 
dipastikan bahwa ia telah menguasai semua aspek yang berhubungan dengan firman Tuhan.

Hal yang berikut adalah bahwa dalam Ezra 7:6 tertulis bahwa Ezra adalah seorang ahli kitab. Dijelaskan pula dalam ayat tersebut bahwa Ezra sebagai ahli kitab, mahir dalam Taurat Musa yang diberikan Tuhan, Allah Israel. Kata ahli kitab sangat berhubungan erat dengan kata "imam." Pendapat ini senada dengan Derek Kidner yang menjelaskan bahwa dalam ayat kedua memberikan penjelasan tentang jabatan Ezra sebagai seorang imam dan juga seorang ahli kitab. ${ }^{24}$ Hal ini terlihat dalam ayat-ayat yang menjelaskan tentang pribadi Ezra. Sebagai contoh, dalam ayat 2 tertulis kata "Ezra, ahli kitab" sedang dalam ayat 3 ditulis dengan kata imam. Jadi dengan kata lain, ahli kitab memiliki pengertian atau tugas yang hampir sama dengan seorang imam, yaitu sebagai orang yang memiliki tugas untuk menyampaikan hukum Tuhan. Dalam ayat yang kelima juga dipakai kata ahli kitab sebagai gelar yang dimiliki Ezra. Gelar yang dimiliki itu membuat ia memiliki kesempatan untuk berdiri di atas mimbar, berdiri lebih tinggi dari semua orang itu (Neh. 8: 6-7). Karena keahlian yang dimilikinya maka ia mampu memberi keterangan-keterangan tentang hukum Taurat sehingga pembacaan dapat dimengerti (ay. 9). Jadi dengan demikian, secara kontekstual, kata ahli kitab memiliki arti orang yang mampu menjelaskan dan memberikan pengertian tentang hukum Taurat secara tepat kepada orang lain hingga menghasilkan respon positif terhadap penjelasan itu.

Ungkapan "ahli kitab" berasal dari kata "ahli" dan kata "kitab." Kata "ahli berarti orang yang mahir, paham sekali dalam suatu ilmu. ${ }^{25}$ Kata itu diterjemahkan dengan kata scribe oleh King James Version. "Scribe" adalah penulis atau pengarang dan juga dapat berarti orang yang menulis salinan buku sebelum mesin cetak ditemukan. Selain itu scribe berarti orang yang membuat salinan tulisan tangan Taurat Musa. ${ }^{26}$ Kata ahli kitab dalam bahasa Ibrani adalah ספָָ (saphar). ${ }^{27}$ Oleh LAI kata itu diterjemahkan sebagai "ahli kitab.” Kata

\footnotetext{
${ }^{24}$ Kidner, Ezra and Nehemia, 104.

${ }^{25}$ Tim Penyusun Pusat Pendidikan dan Pengembangan Bahasa, “Ahli,” dalam Kamus Besar Bahasa Indonesia (Jakarta: Balai Pustaka, 1982), 12.

${ }^{26}$ David B. Guralnik, "Scribe" dalam Webster New Word Dictionary, pen., Clark C. Livensparger dan yang lainya (New York: Simon dan Schuster Publisher, 1979), 662.

${ }^{27}$ John Joseph Owens, Analytical Key to the Old Testament (Grand Rapid: Baker Book House, 1989), 3: 77 .
} 
menceritakan kitab dan juga berarti orang yang terpelajar. ${ }^{28}$ Dalam kitab lain, penggunaan kata ini dapat diterjemahkan sebagai "juru hitung, juru tulis” (2 Raj. 25:19, Yes. 33:18, Yer. 37:15). Dari pengertian-pengertian di atas dapat disimpulkan bahwa ahli kitab menurut arti literal adalah orang yang telah mahir dan memiliki pemahaman tentang kitab dan dapat menceritakan kitab itu kepada orang lain.

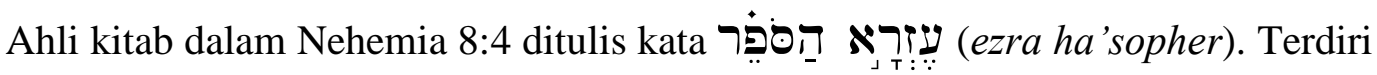
dari kata Ezra dan kata diterjemahkan "ahli kitab" ditambah dengan artikel h yang berarti "Ezra ahli kitab itu."29 Dalam seluruh kitab Perjanjian Lama, kata סָּר dipakai sebanyak 161 kali. Dari pemakaian kata tersebut, sebagian besar penggunaannya dipakai untuk menjelaskan kata "ahli kitab," yaitu sebanyak 50 kali. 40 kali dipakai untuk kata "menceritakan" dan 24 kali dipakai untuk kata "pengumuman", selain itu kata tersebut dipakai untuk menjelaskan kata menghitung, penulis, berbicara, membukukan dan juga memperhitungkan. ${ }^{30}$ Dari penggunaan kata dapat diambil suatu bukti bahwa kata itu menerangkan suatu gelar yaitu "ahli kitab."

Kata lain yang menekankan kompetensi Ezra sebagai seorang yang ahli dalam bidangnya ditunjukkan dalam kitab Ezra 7:6 yaitu dengan kata מָדיריר (mahir), kata sifat yang menjelaskan Ezra sebagai seorang ahli kitab. Penggunaan kata מדזהיר terdapat 4 kali dalam Perjanjian Lama, yang berarti "siap, rajin, dan mempunyai." 31 Penekanan kata ini memberikan pengertian yang jelas tentang kemampuan Ezra dalam menguasai kitab. Dilihat dari penyelidikan konteks dalam nats tersebut mengindikasikan bahwa kemampuan yang dimiliki Ezra berasal dari penyerahan diri Ezra secara mutlak untuk menyelidiki kitab. Penyelidikan tersebut dilakukan dengan cara mengumpulkan hasil penyelidikan, mencermati penyelidikan kitab dan mempelajari kitab secara menyeluruh. $^{32}$

Dari penelitian secara historis, kata "ahli kitab" pertama kali dipakai sebagai gelar para imam. Adanya gelar ahli kitab mulai muncul setelah masa pembuangan

\footnotetext{
${ }^{28}$ Bushell: BibleWorks Hermeneutika, Computer Bible Research Software, [CD ROM]

${ }^{29}$ Owens, Analytical Key to the Old Testament, 3:77.

${ }^{30}$ Strong's, BibleWorks Hermeneutika, Computer Bible Research Software, [CD ROM].

${ }^{31}$ Ibid.

${ }^{32}$ Lawson, "The Pattern of Biblical Preaching an Expository Study of Ezra 7:10 dan Nehemia 8:18," Bibliotecha Sacra, 458.
} 
Babel. Ahli kitab pada masa Ben-Sira bukan termasuk golongan politikus, tetapi pada masa Antiochus Epiphanes ahli kitab memiliki kedudukan sejajar dengan ahli politik. Ahli kitab pada mulanya adalah pelayan dalam ibadah di sinagoge. Beberapa di antara mereka menjadi anggota Mahkamah Agung. ${ }^{33}$ Ahli kitab merupakan gelar baru bagi pemimpin rohani pada masa pasca pembuangan. Gelar baru ini sangat mempengaruhi kehidupan umat Israel pada masa itu. W.A. Lassor berkata:

Gelar baru untuk pemimpin rohani umat itu mengisyaratkan suatu zaman yang baru dalam kehidupan mereka. Zaman itu ditentukan oleh Taurat yang menjadi pusat realitasnya, dan ahli Taurat סָָ (saphar) yang merupakan pemimpin agama yang utama adalah penafsir dan pengulas hukum itu. ${ }^{34}$

Istilah itu mungkin dipengaruhi oleh bahasa Persia. Dalam bahasa Aram berarti pejabat sipil kerajaan, dan tanggung jawabnya dilukiskan dalam ungkapan yang mengikuti istilah itu. Pengaruh itu segera hilang dalam perkembangan pemakaian istilah tersebut di Israel. ${ }^{35}$ Ada tiga fungsi utama ahli Taurat; pertama, memelihara hukum Taurat. Mereka merupakan jalur nalar hukum, pembelanya, terutama pada zaman helenistik, ketika keimaman telah bobrok. Mereka menyampaikan keputusan-keputusan hukum tak tertulis yang telah muncul dalam usaha mereka menerapkan hukum Musa pada kehidupan sehari-hari. ${ }^{36}$ Kedua, mengumpulkan banyak murid dan mengajar mereka tentang hukum, dan ketiga, dalam Perjanjian Baru mereka dipercayai untuk urusanurusan hukum sebagaimana hakim-hakim di Mahkamah Agama. ${ }^{37}$

Dari Interpretasi di atas dapat disimpulkan bahwa kata ahli kitab menjelaskan tentang kompetensi seorang pengkhotbah. Ahli Kitab berarti juga orang yang memiliki pemahaman yang komprehensip terhadap Kitab dan memiliki keahlian dalam mengkomunikasikan firman Allah tersebut. Dilihat dari latar belakang Ezra, ia adalah seorang ahli kitab yang sebelumnya telah belajar secara sungguh-sungguh, dengan tekun dan belajar secara komprehensip (Ezr. 7:6, 10). Bukan hanya itu saja, Ezra juga memenuhi kriteria sebagai orang yang berkompeten dalam bidangnya karena ia sendiri juga adalah seorang pelaku firman. Keberhasilannya dalam menjelaskan firman Allah sehingga pembacaan dimengerti merupakan suatu bukti bahwa ia adalah seorang yang berkompeten. Jadi karakteristik sebuah khotbah adalah disampaikan oleh orang yang

\footnotetext{
${ }^{33}$ Douglas, The New Bible Dictionary, 1151.

${ }^{34}$ Lasor dan yang lainnya, Pengantar Perjanjian Lama 1, 444.

${ }^{35}$ Ibid.

${ }^{36}$ C. L. Feinberg "Taurat," dalam Ensiklopedi Alkitab Masa Kini, peny., H. A. Oppusunggu, pen., Soetarno (Jakarta: Yayasan Komunikasi Bina Kasih, 1999), 2: 454.

${ }^{37}$ Ibid
} 
seharusnya telah menguasai Kitab secara menyeluruh dan yang telah mampu melakukan firman Allah tersebut serta mampu mengajarkan kepada orang lain.

Dengan demikian setiap pengkhotbah seharusnya mengikuti teladan Ezra dan memiliki komitmen untuk belajar Kitab dengan cara berserah, sungguh-sungguh dan komperhensip. Melalui proses tersebut, seorang pengkhotbah bukan saja mengetahui firman Tuhan melainkan juga menguasai semua segi firman itu dan ahli dalam mengkomunikasikannya kepada orang lain.

\section{Didasarkan Pada Teks (ay 4)}

Karakteristik khotbah ekspositori yang kedua menurut Nehemia 8:1-9 adalah bahwa penyampaian sebuah khotbah didasarkan pada teks. Hal ini terlihat dari ayat yang berkata “. . Ia membacakan beberapa bagian-bagian daripada kitab itu. ..” Kata kunci yang memberikan pemahaman tentang kriteria ini adalah kata קר (qara) "membacakan" dan רָָ (saphar) "buku itu."

Pada hari pertama bulan ketujuh (8:2), atas permintaan rakyat yang berkumpul, Ezra membacakan "kitab Taurat, yakni kitab hukum diberikan Tuhan kepada Israel" (ay. 3), mulai pagi hari sampai siang hari, sambil berdiri di atas mimbar kayu di depan pintu gerbang Air (ay. 4). Pada saat yang sama, orang-orang Lewi membacakan dan menafsirkannya sehingga orang banyak itu mengerti pembacaan itu (ay. 9). ${ }^{38}$ Dari kronologis ini, dapat dilihat bahwa Ezra mendasarkan keyakinannya kepada kitab Taurat Musa yang ia bawa. Dilihat dari waktu ia membacakan hukum Taurat, dapat diindikasikan bahwa ia membaca kitab itu secara komprehensip. Buku yang dibawa Ezra kemungkinan besar adalah naskah imami yang dibawa Ezra dari Babel dan yang kemudian menjadi kerangka dari Pentateukh selengkapnya. Steven J. Lawson mengataan bahwa Ezra membacakan firman itu dengan keyakinan yang mendalam dan dengan penuh perhatian. ${ }^{39}$

Dilihat secara kontekstual, tampak salah satu proses dalam liturgi ibadah berupa pembacaan beberapa bagian dari sebuah kitab. Praktek pembacaan firman merupakan suatu unsur penting dalam menyampaikan firman. Kata קרא digunakan untuk menjelaskan pemberitaan Yunus ketika menyampaikan pesan atau firman Allah kepada bangsa di Niniwe ketika ia berseru kepada orang-orang di sana (Yun. 3:4).

\footnotetext{
${ }^{38}$ LaSor, Pengantar Perjanjian Lama, 430.

${ }^{39}$ Lawson, "The Pattern of Biblical Preaching," Bibliotecha Sacra, 463.
} 
Praktek pembacaan Kitab ini terlihat juga dalam Perjanjian Baru. Sebagai contoh dalam pelayanan Yesus, ketika ia berkhotbah di muka umum, ia mengutip atau membacakan kitab Yesaya (Luk. 4:18-19). Pembacaan kitab juga dilakukan oleh Rasul Petrus ketika ia memberitakan firman Allah pada hari Pentakosta dengan mengutip kitab Yoel 2:28-32 dan juga Mazmur 16:8-11; 89:3; 110:1-2 (Kis. 2:17-35).

Kata "membacakan" berasal dari kata קרא (qara). Dalam King James Version קרא menjadi call, invoke, summon, proclaim, appeal to. Menurut Webster New World Dictionary, kata membacakan dapat berarti; 1 . mencari arti dari tulisan atau cetakan dengan memahami setiap huruf-huruf, tanda-tanda dan angka-angka; 2. menyuarakan tulisan atau cetakan; 3. memahami makna asli; 4. belajar. ${ }^{40}$ Dilihat dari kamus bahasa Indonesia, kata "membacakan" berarti membaca nyaring (melisankan tulisan) untuk orang lain. ${ }^{41}$ Dengan melihat arti menurut kamus, kata "membacakan" dalam Nehemia 8:2 dapat disimpulkan sebagai suatu usaha untuk menyampaikan maksud kitab dengan menyuarakan tulisan yang ada dalam kitab tersebut sedemikian rupa sehingga orang lain dapat mendengar dan mengerti.

Kata yang menjelaskan penyampaian khotbah didasarkan pada teks adalah kata

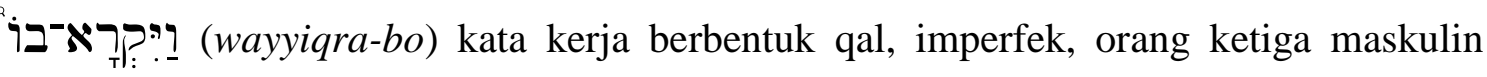
tunggal. Berasal dari akar kata קרא dengan waw konsekutif (!w) dan akhiran kata ganti orang ketiga tunggal o dengan preposisi בר בר (bo) memiliki arti "dalam, di dalam, di samping, dengan, dan bagi. ${ }^{43}$ Kata kerja bentuk qal ada terdiri dari qal stative; menyatakan suatu keadaan atau kondisi dan qal fientive; menyatakan suatu tindakan. ${ }^{44}$ Kala imperfek dipakai dalam bahasa Ibrani untuk suatu kegiatan yang belum selesai. ${ }^{45}$ Waw dengan bentuk imperfect akan disebut preterite dan waw consekutif dan akan menunjuk kepada kegiatan masa lalu sedangkan perfect dengan waw disebut

\footnotetext{
${ }^{40}$ Guralnik, "Read" dalam Webster New Word Dictionary, 610.

${ }^{41}$ Tim Penyusun, "membacakan," dalam Kamus Besar Bahasa Indonesia, 72.

${ }^{42}$ Owens, Analytical Key to the Old Testament, 77.

${ }^{43}$ Carl Reed, Diktat Kuliah: Bahasa Ibrani, Jilid 1, sem. 5, 122.

${ }^{44}$ William, Hebrew Syntax, 1.

${ }^{45}$ Samgar Setia Budi, Dikat Kuliah: Bahasa Ibrani, sem 5, 57.
} 
perfect dan waw konsekutif dan menunjuk kepada kegiatan masa depan. ${ }^{46}$ Jadi dalam

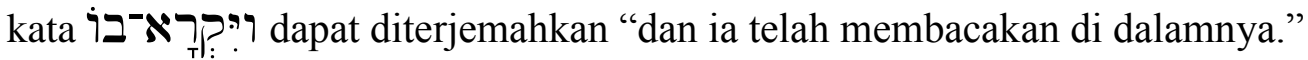

Kata kunci kedua yang membuktikan bahwa khotbah Ezra didasarkan pada teks

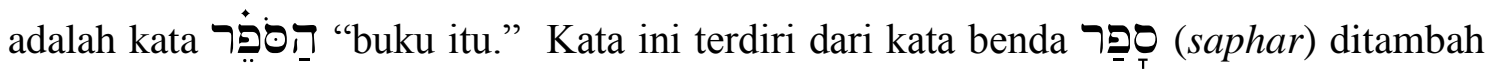
dengan artikel 끄 (ha) ditambah titik dagesh forte pada huruf berikutnya. Dalam bahasa Ibrani, kata benda bisa langsung mengandung arti yang umum atau tidak tertentu. ${ }^{47}$ Konteks yang menentukan apakah artinya umum. Untuk membuat kata benda menjadi tertentu, bahasa Ibrani memakai awalan he dengan vokal patah (﹎. ) "itu."48 Jadi setiap kata benda yang memiliki awalan penentu, kata tersebut menunjuk kepada kata benda tertentu. Dalam Perjanjian Lama, kata untuk menjelaskan kata "kitab" sebanyak 138 kali. Selain itu kata ini diterjemahkan sebagai tulisan, bukti, dan pelajaran."49 Jadi kata הَפּْ dapat diterjemahkan "buku itu."

Dalam konteks tersebut nampak dengan jelas adanya sebuah sumber yang dipakai Ezra sebagai dasar khotbah. Ayat kedua tertulis “. . .lalu pada hari pertama bulan yang ketujuh itu imam Ezra membawa kitab Taurat itu. .." dari nats ini dapat dilihat bahwa buku yang dibaca oleh Ezra adalah kitab Taurat. Taurat berasal dari kata תוֹרדה (torah) artinya hukum. ${ }^{50}$ Jadi kata awalan penentu pada kata "kitab itu" menunjuk kepada kitab Taurat. Dari penyelidikan secara gramatikal ini, dapat diambil satu bukti bahwa Ezra mendasarkan khotbahnya kepada suatu pembacaan yang bersumber dari kitab, yaitu kitab Taurat.

Jika dilihat secara historis, budaya pembacaan Kitab Taurat telah dimulai sejak masa pemerintahan para hakim. Pembacaan hukum Taurat ini terlihat dalam persekutuan-persekutuan yang dilakukan oleh umat Israel jauh sebelum masa pembuangan. Ibadah yang dilakukan oleh umat Israel sebelum masa pembuangan dilakukan di tempat suci di mana kitab hukum disimpan. Tempat suci demikian itu menjadi pusat di mana seluruh suku datang dan berkumpul untuk menyelenggarakan upacara khidmat itu bersama-sama. Dalam budaya Israel, terdapat perayaan utama yaitu

\footnotetext{
${ }^{46}$ Frank Fosdahl, Diktat Kuliah: Ibrani, sem. 5, 24.

${ }^{47}$ Carl Reed, Diktat Kuliah: Bahasa Ibrani, Jilid 1, sem. 5, 13.

${ }^{48}$ Ibid.

${ }^{49}$ Strong's, BibleWorks Hermeneutika, Computer Bible Research Software, [CD Rom].

${ }^{50}$ Carl Reed, Diktat Kuliah: Torah, Sem 1, 1.
} 
perayaan panen yang dilakukan kira-kira bulan September dan Oktober. Pada waktu perayaan ini, orang-orang Israel datang ke Silo dari tempat yang jauh dan dekat (1 Sam. 1). Perayaan itu disebut perayaan Pondok daun, dan dalam kesempatan itu pembacaan kitab hukum dilakukan (Ul. 31:10). ${ }^{51}$ Jadi dapat dilihat di sini bahwa tradisi pembacaan hukum Taurat merupakan suatu unsur ibadah yang dipandang sangat penting bagi orang-orang Israel, mengingat penghormatan mereka terhadap hukum Taurat.

Mendasarkan khotbah kepada teks merupakan salah satu kriteria yang menjadikan khotbah itu alkitabiah. Alasan kriteria ini didukung oleh pendapat seorang penulis yang berkata bahwa teks Alkitab sendiri merupakan sumber terkaya dan teraman yang tepat untuk dikhotbahkan. Lebih lanjut dikatakan bahwa teks-teks yang berisi doktrin-doktrin penting, kisah tentang orang-orang yang memang ada, dan sejumlah tema praktis dan rohani,semuanya merupakan materi eksposisi umum yang sangat kaya. ${ }^{52}$

\section{Dikombinasikan dengan Pujian (ay 6-7)}

Ayat kunci yang memberikan penjelasan terhadap karakteristik ini ialah dalam Nehemia 8:6-7, secara khusus dalam ayat 7 berkata “. . . Lalu Ezra memuji TUHAN, Allah yang maha besar, dan semua orang menyambut dengan: "Amin, amin!", sambil mengangkat tangan." 53 Tertulis bahwa Ezra memuji Tuhan, setelah ia membuka kitab itu. Nampaknya Ezra memuji Tuhan ketika khotbah sedang berlangsung. Dengan kata lain ia menyelingi khotbah itu dengan pujian kepada Allah. Karakteristik khotbah Ezra yang paling menarik adalah bahwa khotbah yang dilakukan Ezra bukan sekedar pendemonstrasian ilmu homelitik, akan tetapi juga dipraktekkan sebagai wujud penyembahan kepada Allah. ${ }^{54}$

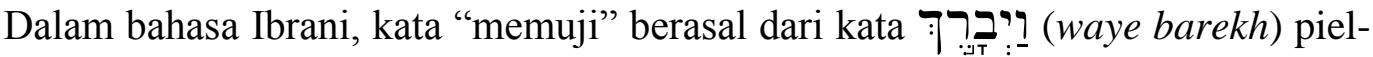
imperfek-orang ketiga-maskulin-tunggal dengan waw konsekutif. ${ }^{55}$ Dalam buku tata bahasa Ibrani yang tua, Piel dianggap yang membuat qal lebih kuat atau intensif, dan berfungsi sebagai “resultif,"yaitu yang menyebabkan suatu hasil dari induk kata

\footnotetext{
${ }^{51}$ Wismo Adi Wahono, Di sini Kutemukan, 126.

${ }^{52}$ Jerry Vines dan Jim Shaddix, Homiletika Kuasa dalam Berkhotbah, pen., Endah Edyahswarawati Handoko, peny., Tjuk Kaihatu (Malang: Gandum Mas, 1999), 130.

${ }^{53}$ Nehemia 8:7.

${ }^{54}$ Bartholomeus Dumgair, wawancara dengan penulis, Sekolah Tinggi Theologia Injili Indonesia, Yogyakarta, 11 Februari 2005.

${ }^{55}$ Owens, Analytical Key to the Old Testament, 78.
} 
kerjanya. ${ }^{56}$ Selain berati memuji, kata ini dapat diterjemahkan "bersujud, memberkati, bersumpah." ${ }^{, 57}$ Dalam penggunaannya, kata בּרך (barakh) pertama kali dipakai untuk menjelaskan peristiwa penciptaan, yaitu ketika ia memberkati semua ciptaannya (Kej. 1:22). Dalam kebudayaan tradisional, menyembah atau memuji merupakan suatu ucapan syukur yang diwujudkan dengan berlutut. ${ }^{58}$

Dilihat dari sisi historis, pujian sebagai salah satu unsur ibadah telah dilakukan sejak masa bapak leluhur Abraham sebagai bentuk ucapan syukur dan penyembahan kepada Allah (Kej. 24:48). Penekanan pujian dalam ibadah juga ditunjukkan dalam sejarah ibadah bangsa Israel (U1. 8:10, Yos. 22:33). Ibadah pada masa pra pembuangan mengutamakan tata cara ibadah dibanding dari segi rohaniah ibadahnya. Hal ini terlihat dari upacara agamawi berupa pencurahan darah, pembakaran kemenyan dan penyampaian berkat imamat serta tata cara ibadah yang lain. ${ }^{59}$ Dalam kebaktian di Sinagoge, terdapat suatu tata cara ibadah yang terdiri dari Shema, doa-doa, pembacaan kitab Suci dan penjelasan. Untuk menaikkan pujian di Bait Suci, orang Lewi mengeluarkan tata cara rinci. Mazmur-mazmur dipakai dalam tata ibadah dan dalam pawai kudus dengan sorak sorai dan nyanyian syukur (Mzm. 42:5). Cara menyanyi barangkali antifonal, melibatkan dua koor, atau solis dan koor. ${ }^{60}$ Hal itu membuktikan bahwa pujian memiliki peranan penting dalam ibadah. Demikian halnya pujian yang diucapkan Ezra kepada Allah merupakan suatu unsur ibadah yang memiliki makna sebagai sarana penyembahan kepada Allah. Dengan melihat realitas historis dalam sejarah perkembangan peribadahan umat Israel, dapat disimpulkan bahwa pujian telah dipakai menjadi salah satu unsur yang penting dalam ibadah.

\section{Disampaikan dengan Hermeneutik yang Benar (ay. 8-9)}

Ezra bukan saja mengkombinasikan khotbah dengan pujian kepada Allah, tetapi juga dalam ayat 9 memberikan suatu penekanan terhadap firman Allah. Hal yang dilakukan Ezra adalah membaca dengan jelas, dan memberi keterangan-keterangan, sehingga pembacaan yang dilakukan Ezra ini dimengerti oleh seluruh pendengar saat itu

\footnotetext{
${ }^{56}$ Carl A. Reed, Dikat Kuliah: Bahasa Ibrani, peny., Samgar Setia Budi, sem. 5, 57.

${ }^{57}$ Vine's: Bible Ekplorer, Software Alkitab, Biblika dan Alat-alat, [CD ROM].

${ }^{58}$ Van Gemeren, The New International Dictionary of Old Testament Theology and Exegesis, vol 1,755

${ }^{59}$ J. G. S. S. Thompson, "Ibadah,” dalam Ensiklopedi Alkitab Masa Kini, pen., Broto Semedi (Jakarta: Yayasan Komunikasi Bina Kasih/OMF, 1992) 1: 408.

${ }^{60}$ R. S. Wallace, "Pujian," dalam Ensiklopedi Alkitab Masa Kini pen., Harun Hadiwijono (Jakarta: Yayasan Komunikasi Bina Kasih/OMF, 1992), 284.
} 
(Neh. 8:9). Pendapat seorang penafsir terhadap proses pembacaan ini hanyalah terjemahan begitu saja (tanpa persiapan) karena kemungkinan pendengar saat itu hanya bisa mengerti bahasa Aram, bukan bahasa Ibrani. ${ }^{61}$ Kitab Perjanjian Lama seperti kitab Hagai, Zakharia, Malachi, 1 dan 2 Tahwarikh, ditulis dalam bahasa Ibrani. Akan tetapi pada masa Ezra, banyak orang Israel yang tidak mengerti bahasa Ibrani, karena kebanyakan mereka lahir di daerah yang tidak mengenal bahasa Ibrani.

Cara yang dilakukan Ezra agar pembacaan kitab dimengerti adalah dengan menjelaskan dan memberi keterangan. Kata keterangan mengindikasikan bahwa ia tidak hanya menterjemahkan kitab tersebut, akan tetapi juga memberikan penjelasanpenjelasan. Penekanan kata "dibacakan dengan jelas" nampak dalam bahasa Ibrani

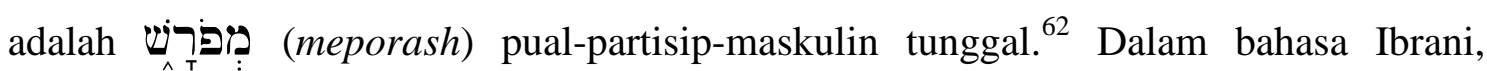
partisip menyatakan kegiatan yang sedang berlangsung dan memiliki beberapa fungsi sintaks antara lain atributif, yaitu sebagai kata sifat yang memberikan keterangan langsung. Selain itu berfungsi sebagai predikatif, substantif dan juga dapat berfungsi sama seperti klausa penghubung. ${ }^{63}$ Dalam kalimat ini, partisip berfungsi untuk memberikan keterangan langsung, yaitu menerangkan kata kerja “dibaca." Dengan demikian proses pembacaan itu dilakukan dengan jelas artinya dapat mencakup dari segi intonasi suara, gaya bahasa, gaya bicara dan juga intensitas suaranya.

Selanjutnya, karakteristik khotbah Ezra dapat dilihat dari penekanan kata "diberi

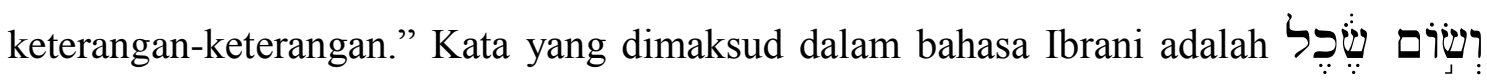
(we'som shekel). King JamesVersion menerjemahkan kata itu dengan kata gave the

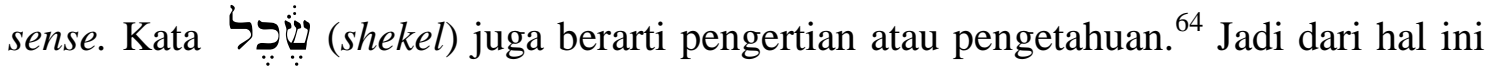
dilihat bahwa keterangan yang dimaksud adalah berupa penjelasan atau pengetahuan yang disampaikan untuk tujuan memberikan keterangan. Dari keterangan yang diberikan baik berupa terjemahan bahasa, ilustrasi ataupun berupa eksposisi dari kitab yang telah dipelajari Ezra sebelumnya dapat dilihat dampak pembacaan kitab tersebut yaitu dapat dimengerti oleh semua orang yang mendengar khotbah itu.

Langkah-langkah hermeneutik yang dilakukan Ezra yang antara lain pembacaan kitab dengan jelas dan pemberian keterangan-keterangan, mengarah kepada satu tujuan

\footnotetext{
${ }^{61}$ Thompson, "Nehemia," dalam Tafsiran Alkitab Masa Kini, 1: 665.

${ }^{62}$ Owens, Analytical Key to the Old Testament, 3: 78.

${ }^{63}$ Reed, Dikat Kuliah: Bahasa Ibrani, peny. Samgar Setia Budi, Sem 5, 57.

${ }^{64}$ Wilson, Old Testament Word Studies, 380.
} 
yang jelas yaitu pengertian dari pendengar. Seorang penulis memberi penafsiran bahwa kata "dibacakan dengan jelas" bisa saja menunjuk kepada suatu terjemahan begitu saja (tanpa persiapan), disebabkan karena ada beberapa orang yang mengerti bahasa Aram, bukan bahasa Ibrani. ${ }^{65}$ Beberapa faktor yang menyebabkan perlunya penafsiran dan penjelasan ialah adanya perbedaan antara bahasa yang dipakai dalam kitab dengan perkembangan bahasa yang dipakai orang Israel pada masa itu. Usaha pemberian keterangan baik itu berupa penerjemahan bahasa atau penyampaian hasil eksegesa telah dilakukan dalam ibadah-ibadah umat Israel pada masa pra pembuangan dan juga ibadah di Sinagoge. ${ }^{66}$ Hal itu menjadi salah satu bagian dari tata cara ibadah yang telah disusun sedemikian rupa sehingga supaya pendengar mengerti pembacaan kitab Taurat dan juga kitab Nabi-nabi.

Tujuan pemakaian hermeneutik terlihat dalam ayat 9 di mana tertulis bahwa pembacaan kitab dimengerti oleh pendengar. Ezra telah memberikan suatu teladan dalam menggunakan prinsip hermeneutik untuk mencapai suatu sasaran khotbah. Pemakaian hermeneutik yang benar dapat dilakukan oleh orang yang memiliki ketrampilan, pengetahuan yang komprehensip dan juga keahlian dalam bidangnya. Data pribadi Ezra telah membuktikan bahwa ia adalah seorang yang memiliki kompetensi dalam hal itu. Oleh karena itu, khotbah Ezra mencapai suatu sasaran yang jelas berupa pemahaman terhadap pembacaan kitab taurat oleh pendengar. Ayat yang berbunyi "bagian-bagian dari pada kitab itu, yakni Taurat Allah, dibacakan dengan jelas, dengan diberi keterangan-keterangan, sehingga pembacaan dimengerti" (Neh. 8:9). Memberikan informasi yang jelas tentang tiga kriteria hermeneutik yaitu adanya penekanan kepada teks, pemberian keterangan dan juga eksposisi yang mengakibatkan pembacaan itu dimengerti.

\section{Dampak Khotbah Ezra}

Dampak khotbah Ezra dalam Nehemia 8:1-9 terlihat dengan jelas dalam Nehemia 10-13. Dampak dari pembacaan Taurat itu antara lain timbulnya penyesalan terhadap dosa-dosa. Hal ini ditunjukkan dengan respon umat Israel ketika mereka mendegar pembacaan Taurat (ay. 10). Selanjutnya respon terhadap pembacaan Taurat itu dilakukan dengan pengakuan dosa dan berdoa kepada Allah (Neh. 10:1-3). Awal kebangunan rohani ini berlanjut kepada pemulihan bangsa Israel baik secara fisik

\footnotetext{
${ }^{65}$ Thompson, Tafsiran Alkitab Masa Kini, 1: 667.

${ }^{66}$ Wallace, "Pujian," dalam Ensiklopedi Alkitab Masa Kini, 2: 284.
} 
maupun rohani. Pemimpin-pemimpin membubuhi materai mereka pada perjanjian untuk mengikuti hukum Taurat (Neh. 9:38, 10:1).

Pemulihan rohani ditunjukkan dengan adanya sumpah untuk hidup menurut hukum Allah (ay. 28-29). Pembacaan kitab Taurat juga membawa penyelesaian terhadap masalah perkawinan campuran (ay. 30), penghormatan hari sabat, dukungan terhadap pelayaan bait Allah dengan memberi sepertiga syikal setiap tahun. Mereka juga menyumbang kayu bakar untuk mezbah, memberi hasil yang pertama kepada Tuhan (ay. 35), dan juga memberi perpuluhan (ay. 37). Secara fisik dapat dilihat pemulihan dalam bidang administrasi di bawah pemerintahan Nehemia (Neh. 13). Dengan melihat dampak khotbah Ezra yang berupa kebangunan rohani dan perubahanperubahan yang terjadi pada bangsa Israel, dapat diambil suatu kesimpulan bahwa transformasi suatu bangsa dimulai dari sebuah khotbah yang Alkitabiah.

\section{Kesimpulan}

Dari keempat karakteristik khotbah yang ada dalam Nehemia 8:1-9 dapat diambil suatu perbandingan dengan pemahaman Khotbah Ekspositori secara umum. Dalam bab sebelumnya telah dibahas tentang unsur khotbah yang di dalamnya tercakup unsur penafsiran, komunikasi dan pesan. Dalam karakteristik khotbah yang telah diteliti pada bab ini menunjukkan suatu perkembangan pemikiran tentang pola khotbah ekspositori sebagai suatu bentuk khotbah yang alkitabiah. Perkembangan pemikiran itu terletak kepada beberapa prinsip antara lain tentang kompetensi seorang pengkhotbah, dan juga praktek pengkombinasian khotbah terhadap pujian sebagai wujud pelayanan dan penyembahan kepada Allah.

Dengan memperoleh pemahaman tentang karakteristik khotbah dalam kitab Nehemia, maka Nehemi 8:1-9 dapat di jadikan sebuah contoh khotbah ekspositori. Jadi bagi seseorang yang hendak menyampaikan khotbah ekspositori sudah sepatutnya memegang prinsip sebagai berikut; pertama, harus memiliki pengetahuan yang luas tentang firman Tuhan. Hal ini sangat diperlukan mengingat dalam khotbah Ekpositori merupakan khotbah yang memerlukan ketrampilan dan kemampuan khususnya dalam menggali isi Alkitab. Kedua, khotbah harus tetap berdasarkan kepada teks sebagai pedoman untuk memperoleh pengajaran. Pengajaran dari luar hanya bisa dipakai sebagai alat untuk perbandingan dan bukan sebagai dasar utama untuk mengambil suatu pedoman. Oleh karena itu untuk menghindari hal-hal yang tidak alkitabiah, maka kesetiaan pada teks sangat diperlukan dalam sebuah khotbah Ekspositori, sehingga 
dengan demikan khotbah itu akan terarah dengan jelas. Ketiga, khotbah ekspositori bukanlah suatu pendemonstrasian ketrampilan dalam menggali, mengolah dan penyampaian firman Tuhan, akan tetapi yang lebih penting adalah sebagai suatu wujud pelayanan dan pujian kepada Allah. Jadi akan lebih baik jika ada kombinasi antara khotbah dan pujian. Keempat, dalam khotbah ekspositori ketrampilan khusus dalam mengkomunikasikan isi kitab sangat diperlukan. Pengkhotbah harus memiliki kemampuan dalam menjelaskan isi Alkitab kepada pendengar. Dengan kata lain, harus memakai prinsip hermeneutik yang benar.

\section{Referensi}

Baxter, J. Sidlow Menggali Isi Alkitab, peny., G. M. A Nainggolan dan H. A.

Brown, Michael L. New International Dictionary of Old Testament Theology and Exegesis, Cumbria: Paternoster Press, 1996

Bushell, Michael S. BibleWorks Hermenutika, Computer Bible Research Software, [CD $\mathrm{ROM}]$

Harris, Laird. Theological Wordbook of the Old Testament, Chichago: Mody Press, 1981

Lasor, W.S., dkk. Pengantar Perjanjian Lama 1, Jakarta: BPK Gunung Mulia, 1996

Lawson, Steven J. "The Pattern of Biblical Preaching an Expository Study of Ezra 7:10 dan Nehemia 8:18," dalam Bibliotecha Sacra, October-Desember 2001

Livensparger, Clark C. Webster New Word Dictionary, New York: Simon dan Schuster Publisher, 1979

Oppusunggu, H. A. Ensiklopedi Alkitab Masa Kini, Jakarta: Yayasan Komunikasi Bina Kasih, 1999.

Owens, John Joseph. Analytical Key to the Old Testament, Grand Rapid: Baker Book House, 1989

Rey, Kevin Tonny. "KHOTBAH PENGAJARAN VERSUS KOTBAH

KONTEMPORER.” DUNAMIS ( Jurnal Teologi dan Pendidikan Kristiani ) Vol.1, no. 1 (2016): 31-51. www.sttintheos.ac.id/e-journal/index.php/dunamis.

Strong's, BibleWorks Hermeneutika, Computer Bible Research Software, [CD ROM].

Theological Wordbook of the Old Testatement, Bible Explorer, Copyright 1995,

Epiphhany Software. All rights reserved. [CD-ROM].

Tim Penyusun Pusat Pendidikan dan Pengembangan Bahasa, "Ahli," dalam Kamus

Besar Bahasa Indonesia, Jakarta: Balai Pustaka, 1982

Van Gemeren, The New International Dictionary of Old Testament Theology and Exegesis, vol 1

Vines, Jerry dan Shaddix, Jim. Homiletika Kuasa dalam Berkhotbah, Malang: Gandum Mas, 1999

Wahono, Wismo Adi. Di sini Kutemukan, Jakarta: BPK Gunung Mulia, 1989

Wilson,William Old Testament Word Studies, McLean: Mac Donald Publlishing Co., tt 